\title{
Awareness and Attitudes About HIV Among Pregnant Women in Aksu, Northwest China
}

\author{
Rena Maimaiti ${ }^{1}$ and Rune Andersson ${ }^{*}, 2$ \\ ${ }^{I}$ Child Preventive Care Department of First Affiliated Hospital, Xinjiang Medical University, Urumqi, and Xinjiang, \\ China \\ ${ }^{2}$ Research and Development Centre, Skaraborg Hospital, Skövde, Sweden
}

\begin{abstract}
The Xinjiang Uyghur Autonomous Region has a firmly established HIV epidemic among its intravenous drug user (IDU) population. Local sex workers were also found to be positive in 1998. A descriptive, cross-sectional survey of knowledge about HIV/AIDS and attitudes among consecutively selected pregnant women was conducted November 2005 in Aksu Prefecture, north-western China, with a population on 2 million with about 25000 pregnancies per year. A total of 291 pregnant women participated. We found a limited knowledge on mother-to child transmission with several misconceptions. The AIDS campaigns have been successful in making all the women aware of HIV as a sexually transmitted disease. However, the common belief that social contact causes transmission gives a high risk that patients are stigmatized. Obviously, it is important to design HIV information strategies that target pregnant women in north-western China.
\end{abstract}

\section{INTRODUCTION}

Vertical transmission of HIV from mother to child is responsible for as many as $90 \%$ of HIV infections among children [1]. Of this, breastfeeding contributes to at least $10 \%[2$, 3]. One study showed $0.7 \%$ transmission per month of breastfeeding at age 2-6 months, and an incidence of $0.3 \%$ per month at age 12-17 months [2]. Mother to child transmission (MTCT) of HIV can be largely eliminated. Numerous clinical trials over the past decade have demonstrated that it is possible to reduce the MTCT risk to less than $2 \%$ [3-7].

In developed and high-income countries, mother to child transmission has been reduced thanks to a combination of modern antiviral therapy and avoidance of breastfeeding. Several studies have shown that formula feeding in resourcepoor settings increases infant mortality owing to infectious diseases [8,9]. This is especially critical in the first six months of life [8]. The most common mode of feeding in these areas is mixed breastfeeding (i.e. supplement in addition to breast feeding), which is associated with increased mortality and morbidity as well as the highest rates of vertical transmission of HIV [10]. Pregnancy has not been proved to have any evident negative effects on women with asymptomatic HIV in developed countries; however, in less developed countries it seems that there is often an increase in the risk of spontaneous abortion and premature birth [11].

Caesarean section has been shown to reduce vertical HIV transmission, and should be advised, but its usefulness in women with fully suppressed viraemia, under good obstetric conditions, is unclear [12]. The risk of transmission is

*Address correspondence to this author at the Research and Development Centre, Skaraborg Hospital, Skövde, Sweden; Tel: +46 500 431137; Fax: +46 500- 431121; E-mail: rune.andersson@vgregion.se directly related to the maternal plasma viral load. It is therefore recommended to suppress HIV to undetectable viral load during the last 8-12 weeks of pregnancy. Zidovudine has been shown to reduce transmission also when given as monotherapy [13]. Intravenous zidovudine during labour and delivery is often given; however, the benefit of this specific approach when viral load is fully suppressed is uncertain [13-17]. Single-dose nevirapine to HIV positive women and their infants at the time of delivery is the most used prophylaxis in developing countries [18]. Comprehensive prevention of mother-to-child-transmission (PMTCT) programmes report substantially lower rates of perinatal transmission, of between $2 \%$ and $5 \%$ in non-breastfed populations [19-21].

China's first case of AIDS was identified 1985 in Beijing [22]. A Joint Assessment of HIV/AIDS Prevention, Treatment and Care in China (2004) [23], developed by UNAIDS and State Council of China, estimated that China had 840,000 people living with HIV/AIDS. This figure has been revised down to 650,000 in 2005 in light of more representative data collection and more appropriate estimation methods [24].

It has been estimated that around $44 \%$ of HIV infections in China are the result of drug use, $24 \%$ are attributable to commercial blood and plasma donation, and $20 \%$ arise from heterosexual intercourse. Sex between men accounted for $11 \%$ of infections, use of blood and blood products for $0.6 \%$, and mother-to-child transmission for $0.5 \%$ [25].

The Xinjiang Uyghur Autonomous Region has a firmly established HIV epidemic among its intravenous drug user (IDU) population. While the vast majority of HIV cases in this region are related to IDU, local prostitutes were also found to be positive in 1998, although the low number tested makes it impossible to draw conclusions as to the extent of heterosexual spread. According to the local disease control centre 16,035 HIV positive patients were reported at the end of June 2006, a rise of 4,732 in just nine months. The region 
reported 11,303 HIV positive at the end of September 2005, according to the same regional centre. The new cases were found in 15 prefectures and cities, including the regional capital, Urumqi.

\section{AIM OF THE SURVEY}

Our aim was to investigate knowledge and awareness about HIV/AIDS among pregnant women in Aksu, Xinjiang, China as background for the planned prevention program.

\section{METHODS AND PARTICIPANTS}

Aksu Prefecture has a population of 2 million of which 380,000 are living in the city. There are about 25,000 pregnancies annually in the prefecture of which 4000 pregnancies are in the city. In November 2005 questionnaire was given to 450 consecutive pregnant women at eight antenatal clinics and answered by 291(65\%). It was modified from a questionnaire constructed by Prof Glen Mola at the Papua New Guinea [26] and consisted of 32 questions divided into three categories: General questions, knowledge about HIV/AIDS, and attitudes toward HIV/AIDS. The questions were both in Chinese and Uyghur. One of us (Rena Maimaiti) was available to clarify the questions if needed. The results were related to age, education level, socio-economic status, work situation, ethnic group and religion. The pregnant women were informed that answering the questionnaires was voluntary and that the information would be handled confidentially and presented in a way that no individual person could be identified.

\section{STATISTICS}

The 95\% confidence intervals (CI) for proportions were calculated with the formula: mean value $(\mathrm{p})+/-1.96 \times \sqrt{ }(\mathrm{p} \times$ $(100-p) / n)$, were $n$ is number of observations and $p$ is proportion in percent. The formula was used when $\mathrm{p} \times \mathrm{n}>500$ and $(100-p) \times n>500$ [27]. If two intervals are not overlapping the observed difference is significant with $p<0.05$.

\section{RESULTS}

\section{Participants}

Out of the 291 women answering the questionnaires 234 were Uyghur and 57 Han Chinese (Table 1). Their ages ranged from 19 to 36 with a mean age of 27.5 years.

The respondents' educational backgrounds and work situations are presented in Tables $\mathbf{2}$ and 3. Thirteen per cent of the Uyghurs and $79 \%$ of the Han Chinese respondents were living in the city, $86 \%$ and $21 \%$ respectively were living in the country side.

\section{Knowledge About HIV}

The women were asked if they had heard about the sickness called HIV or AIDS and in the Uyghur group, $87 \%$ answered that they had and 10\% that they had not, 3\% did not answer the question. In the Han Chinese group, $74 \%$ answered that they had and $19 \%$ that they had not, $7 \%$ did not answer. Seventy-seven percent of the Uyghur group and $65 \%$ of the Han Chinese group had first heard about HIV in the media (Fig. 1).
Table 1. Age Distribution

\begin{tabular}{|c|c|c|}
\hline Age Distribution (Years) & $\begin{array}{c}\text { Uyghur (n=234) } \\
\text { Percent (95 \% CI) }\end{array}$ & $\begin{array}{c}\text { Han }(\mathbf{n}=\mathbf{5 7}) \\
\text { Percent } \mathbf{( 9 5} \text { \% CI) }\end{array}$ \\
\hline \hline 20 or below & $\begin{array}{c}24 \\
(19-29)\end{array}$ & 5 \\
\hline $21-23$ & $\begin{array}{c}19 \\
(14-24)\end{array}$ & $\begin{array}{c}19 \\
(9-29)\end{array}$ \\
\hline $24-26$ & $\begin{array}{c}21 \\
(16-26)\end{array}$ & $\begin{array}{c}32 \\
(20-44)\end{array}$ \\
\hline $27-29$ & $\begin{array}{c}14 \\
(10-18)\end{array}$ & $\begin{array}{c}26 \\
(15-37)\end{array}$ \\
\hline $30-32$ & $\begin{array}{c}10 \\
(6-14)\end{array}$ & 5 \\
\hline $33-35$ & 6 & 3 \\
\hline 36 or above & $(3-9)$ & 5 \\
\hline
\end{tabular}

Table 2. Level of Education Among Pregnant Women in Aksu

\begin{tabular}{|c|c|c|}
\hline Educational Background & $\begin{array}{c}\text { Uyghur }(n=234) \\
\text { Percent }(95 \% \text { CI })\end{array}$ & $\begin{array}{c}\text { Han }(n=57) \\
\text { Percent }(95 \% \text { CI })\end{array}$ \\
\hline No education & $\begin{array}{c}5 \\
(2-8)\end{array}$ & 5 \\
\hline Primary education & $\begin{array}{c}34 \\
(28-40)\end{array}$ & $\begin{array}{c}9 \\
(2-16)\end{array}$ \\
\hline High school & $\begin{array}{c}44 \\
(38-50)\end{array}$ & $\begin{array}{c}39 \\
(26-52)\end{array}$ \\
\hline Tertiary college & $\begin{array}{c}9 \\
(5-13)\end{array}$ & $\begin{array}{c}26 \\
(15-37)\end{array}$ \\
\hline College/University & $\begin{array}{c}8 \\
(5-11)\end{array}$ & $\begin{array}{c}21 \\
(10-32)\end{array}$ \\
\hline
\end{tabular}

We noted frequent misconceptions among the believed routes of HIV transmission (Table 4). Thirty-nine percent of the Uyghur and $47 \%$ of the Han-Chinese women knew that it is no risk in shaking hands. Only $21 \%$ of the Uyghur women could mention one symptom caused by HIV, compared to more than $90 \%$ of the Han Chinese women (Table 5).

There was a tendency toward more correct answers among the Han Chinese as compared with the Uyghurs to all questions about transmission routes.

Ten per cent of the Uyghur women and 4\% of the Han Chinese women thought that you can see if a person is infected with HIV/AIDS by just looking at them, $25 \%$ of the Uyghur women and $32 \%$ of the Han Chinese women wrote they did not know.

On the question as to whether there are special groups who are more often infected with HIV than others, 53\% of the Uyghur women and $7 \%$ of the Han Chinese women wrote that they did not know, $6 \%$ of the Uyghur and $33 \%$ of the Han Chinese women mentioned drug users, $3 \%$ and $25 \%$ 

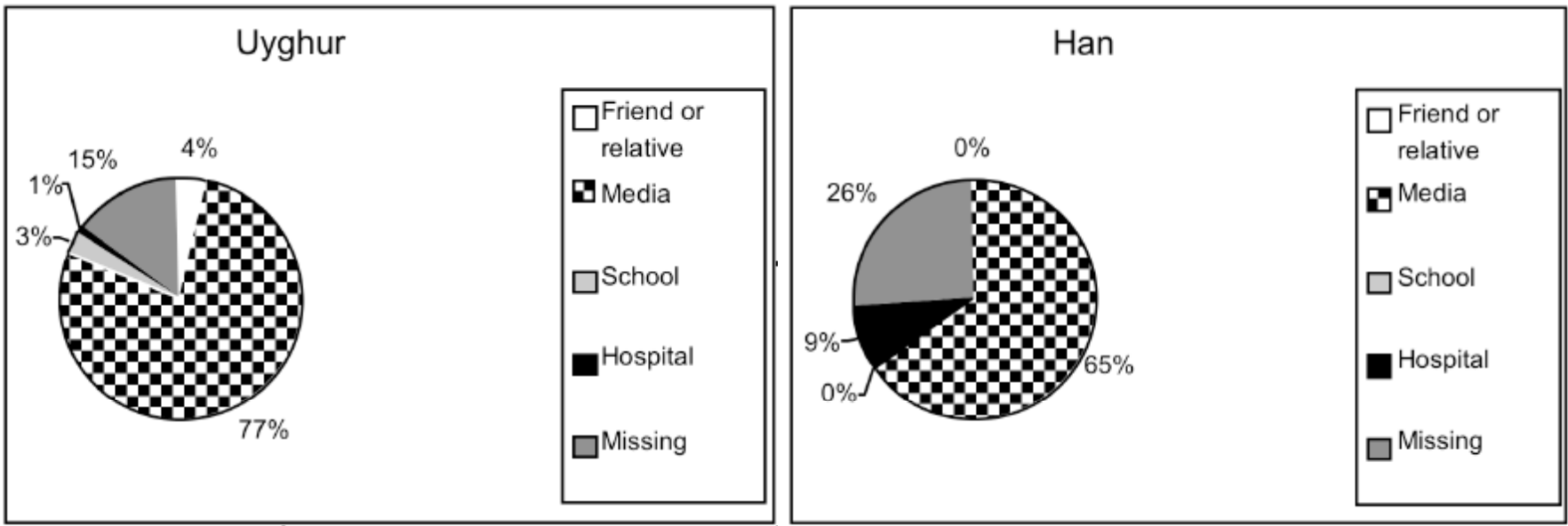

Fig (1). Reported first information among 291 pregnant women about HIV/AIDS.

of them wrote sex workers, $1 \%$ and $7 \%$ listed blood donors, $1 \%$ and $2 \%$ mentioned delivery. Thirty-six percent of the Uyghur and $26 \%$ of the Han Chinese women did not answer.

Table 3. Work Situations Among Pregnant Women and Their Husbands

\begin{tabular}{|c|c|c|}
\hline $\begin{array}{c}\text { Work Situation } \\
\text { Among the Women }\end{array}$ & $\begin{array}{c}\text { Uyghur (n=234) } \\
\text { Percent (95 \% CI) }\end{array}$ & $\begin{array}{c}\text { Han (n=57) } \\
\text { Percent (95 \% CI) }\end{array}$ \\
\hline \hline Unemployed & $\begin{array}{c}62 \\
(56-68)\end{array}$ & $\begin{array}{c}36 \\
(24-48)\end{array}$ \\
\hline Self-employed & $\begin{array}{c}19 \\
(14-24)\end{array}$ & $\begin{array}{c}25 \\
(14-36)\end{array}$ \\
\hline Labourers & $\begin{array}{c}4 \\
(1-7)\end{array}$ & $\begin{array}{c}23 \\
(12-34)\end{array}$ \\
\hline Professional & $\begin{array}{c}12 \\
(8-16)\end{array}$ & $\begin{array}{c}12 \\
(4-20)\end{array}$ \\
\hline No answer & 4 & 5 \\
\hline Husband's & $\begin{array}{c}\text { Uyghur (n=234) } \\
\text { Percent (95 \% CI) }\end{array}$ & $\begin{array}{c}\text { Han (n=57) } \\
\text { Percent (95 \% CI) }\end{array}$ \\
\hline \hline Unemployed & $\begin{array}{c}32 \\
(26-38)\end{array}$ & $\begin{array}{c}21 \\
(10-32)\end{array}$ \\
\hline Self-employed & $\begin{array}{c}49 \\
(43-55)\end{array}$ & $\begin{array}{c}33 \\
(21-45)\end{array}$ \\
\hline Labourers & $\begin{array}{c}16 \\
(6-26)\end{array}$ \\
\hline Professional & $\begin{array}{c}25 \\
(1-7)\end{array}$ & 5 \\
\hline No answer & 7 & $(146)$ \\
\hline
\end{tabular}

About the estimated rate of adults infected with HIV in Xinjiang, $70 \%$ of the Uyghur and $51 \%$ of the Han Chinese women wrote that they did not know, $4 \%$ and $11 \%$ thought it was $1 / 1000$.

On the question about the main transmission route, $22 \%$ of the Uyghur and 5\% of the Han Chinese women answered that they did not know, details are shown in Table 6.
Table 4. Believed Routes of Transmission

\begin{tabular}{|c|c|c|c|c|}
\hline Uyghur $(n=234)$ & $\begin{array}{c}\text { Yes } \\
\text { Percent } \\
(95 \% \text { CI })\end{array}$ & $\begin{array}{c}\text { No } \\
\text { Percent } \\
(95 \% \text { CI })\end{array}$ & $\begin{array}{c}\text { Don't Know } \\
\text { Percent } \\
(95 \% \text { CI })\end{array}$ & $\begin{array}{l}\text { No Answer } \\
\text { Percent }\end{array}$ \\
\hline Eating together & $\begin{array}{c}13 \\
(9-17)\end{array}$ & $\begin{array}{c}40 \\
(34-46)\end{array}$ & $\begin{array}{c}15 \\
(10-20)\end{array}$ & 32 \\
\hline $\begin{array}{c}\text { Shaking } \\
\text { hands/hugging }\end{array}$ & $\begin{array}{c}16 \\
(11-21)\end{array}$ & $\begin{array}{c}39 \\
(33-45)\end{array}$ & $\begin{array}{c}16 \\
(11-21)\end{array}$ & 29 \\
\hline $\begin{array}{c}\text { Caring for } \\
\text { AIDS patients }\end{array}$ & $\begin{array}{c}11 \\
(7-15)\end{array}$ & $\begin{array}{c}36 \\
(30-42)\end{array}$ & $\begin{array}{c}21 \\
(16-26)\end{array}$ & 32 \\
\hline Kissing & $\begin{array}{c}42 \\
(36-48)\end{array}$ & $\begin{array}{c}21 \\
(16-26)\end{array}$ & $\begin{array}{c}18 \\
13-23)\end{array}$ & 18 \\
\hline Sexual contacts & $\begin{array}{c}75 \\
(69-81)\end{array}$ & 1 & $\begin{array}{c}9 \\
(5-13)\end{array}$ & 15 \\
\hline Injection & $\begin{array}{c}56 \\
(50-62)\end{array}$ & $\begin{array}{c}11 \\
(7-15)\end{array}$ & $\begin{array}{c}12 \\
(18-16)\end{array}$ & 21 \\
\hline Breast feeding & $\begin{array}{c}61 \\
(55-67)\end{array}$ & $\begin{array}{c}9 \\
(5-13)\end{array}$ & $\begin{array}{c}11 \\
(7-15)\end{array}$ & 19 \\
\hline $\operatorname{Han}(n=57)$ & $\begin{array}{c}\text { Yes } \\
\text { Percent } \\
(95 \% \text { CI })\end{array}$ & $\begin{array}{c}\text { No } \\
\text { Percent } \\
(95 \% \text { CI })\end{array}$ & $\begin{array}{c}\text { Don't Know } \\
\text { Percent } \\
(95 \% \text { CI })\end{array}$ & $\begin{array}{c}\text { No Answer } \\
\text { Percent }\end{array}$ \\
\hline Eating together & 2 & $\begin{array}{c}54 \\
(41-67)\end{array}$ & $\begin{array}{c}19 \\
(9-29)\end{array}$ & 26 \\
\hline $\begin{array}{c}\text { Shaking } \\
\text { hands/hugging }\end{array}$ & 5 & $\begin{array}{c}47 \\
(34-60)\end{array}$ & $\begin{array}{c}21 \\
(10-32)\end{array}$ & 26 \\
\hline $\begin{array}{l}\text { Caring for } \\
\text { AIDS patients }\end{array}$ & 2 & $\begin{array}{c}53 \\
(40-66)\end{array}$ & $\begin{array}{c}32 \\
(20-44)\end{array}$ & 14 \\
\hline Kissing & $\begin{array}{c}19 \\
(9-29)\end{array}$ & $\begin{array}{c}32 \\
(20-44)\end{array}$ & $\begin{array}{c}26 \\
(15-37)\end{array}$ & 23 \\
\hline $\begin{array}{l}\text { Sexual } \\
\text { contacts }\end{array}$ & $\begin{array}{c}61 \\
(48-74)\end{array}$ & 5 & $\begin{array}{c}21 \\
(10-32)\end{array}$ & 12 \\
\hline Injection & $\begin{array}{c}51 \\
(38-64)\end{array}$ & $\begin{array}{c}18 \\
(8-28)\end{array}$ & $\begin{array}{c}21 \\
(10-32)\end{array}$ & 11 \\
\hline Breast feeding & $\begin{array}{c}47 \\
(34-60)\end{array}$ & $\begin{array}{c}9 \\
(2-16)\end{array}$ & $\begin{array}{c}32 \\
(20-44)\end{array}$ & 12 \\
\hline
\end{tabular}


Table 5. Knowledge About Symptoms of HIV Among 291 Pregnant Women in Aksu, China

\begin{tabular}{|c|c|c|c|}
\hline & $\begin{array}{c}\text { Uyghur }(n=234) \\
\text { Percent } \\
(95 \% \text { CI })\end{array}$ & $\begin{array}{c}\text { Han }(n=57) \\
\text { Percent } \\
(95 \% \text { CI })\end{array}$ & $\begin{array}{c}\text { Total }(\mathbf{n}=291) \\
\text { Percent } \\
(95 \% \text { CI })\end{array}$ \\
\hline Fever & $\begin{array}{c}6 \\
(3-9)\end{array}$ & $\begin{array}{c}37 \\
(24-50)\end{array}$ & $\begin{array}{c}12 \\
(8-16)\end{array}$ \\
\hline Weight loss & $\begin{array}{c}6 \\
(3-9)\end{array}$ & $\begin{array}{c}18 \\
(8-28)\end{array}$ & $\begin{array}{c}8 \\
(5-11)\end{array}$ \\
\hline Cough & 1 & 5 & $\begin{array}{c}2 \\
(0.4-3.6)\end{array}$ \\
\hline Lymphadenopathy & $\begin{array}{c}3 \\
(1-5)\end{array}$ & 4 & $\begin{array}{c}3 \\
(1-5)\end{array}$ \\
\hline Fatigue & $\begin{array}{c}3 \\
(1-5)\end{array}$ & 7 & $\begin{array}{c}3 \\
(1-5)\end{array}$ \\
\hline Low immunity & 0 & $\begin{array}{c}12 \\
14-20)\end{array}$ & $\begin{array}{c}2 \\
(0.4-3.6)\end{array}$ \\
\hline Rash & 0 & $\begin{array}{c}9 \\
(2-16)\end{array}$ & $\begin{array}{c}2 \\
(0.4-3.6)\end{array}$ \\
\hline Diarrhoea & 2 & 0 & 1 \\
\hline Don't know & $\begin{array}{c}53 \\
(42-62)\end{array}$ & $\begin{array}{c}14 \\
(5-23)\end{array}$ & $\begin{array}{c}45 \\
(36-54)\end{array}$ \\
\hline No answer & 29 & 19 & 27 \\
\hline
\end{tabular}

Table 6. Believed Main Routes by which HIV/AIDS is Spread from one Person to another. Some of the Women Selected More than One Route

\begin{tabular}{|c|c|c|}
\hline & $\begin{array}{c}\text { Uyghur (n=234) } \\
\text { Percent (95 \% CI) }\end{array}$ & $\begin{array}{c}\text { Han (n=57) } \\
\text { Percent (95 \% CI) }\end{array}$ \\
\hline \hline Injection drug use & $\begin{array}{c}14 \\
(10-18)\end{array}$ & $\begin{array}{c}26 \\
(15-37)\end{array}$ \\
\hline Sexual contacts & $\begin{array}{c}37 \\
(31-43)\end{array}$ & $\begin{array}{c}51 \\
(38-64)\end{array}$ \\
\hline Blood transfusion & $\begin{array}{c}19 \\
(14-24)\end{array}$ & $\begin{array}{c}30 \\
(18-42)\end{array}$ \\
\hline Mother to child & $\begin{array}{c}10 \\
(6-14)\end{array}$ & $\begin{array}{c}16 \\
(6-26)\end{array}$ \\
\hline Don't know & 22 & 5 \\
\hline No answer & $(17-27)$ & 4 \\
\hline
\end{tabular}

\section{Attitudes Towards HIV Test}

Sixty-nine percent of the Uyghur and $58 \%$ of the Han Chinese women wanted to find out if they were HIV positive, $48 \%$ of the Uyghur and $52 \%$ of the Han Chinese women reported that their reason for wanting to be tested was that they want to receive treatment early. The reason stated by $14 \%$ and $42 \%$ was that they did not want to spread the disease to others. Fourteen percent of the Uyghur and
$18 \%$ of the Han Chinese women did not want to be tested for HIV. The most common reason for not wanting to be tested, in $33 \%$ of Uyghur and $60 \%$ of Han Chinese women, was that they could not accept a positive diagnosis or was afraid. Another reason was that the women thought that they did not have HIV/AIDS.

\section{Attitudes on Disclosure of HIV}

If they were HIV positive, $46 \%$ of the Uyghur and $40 \%$ of the Han Chinese women thought they would inform their husband. Thirty-five percent of the Uyghur and $26 \%$ of the Han Chinese wrote they would inform their family, 53\% of the Uyghur and $51 \%$ of the Han Chinese women would inform their doctor. Most Uyghur women, 70\%, thought that they would get help from their parents if they were found to be HIV positive, $21 \%$ of the Han Chinese women gave the same answer (Table 7).

Table 7. Attitudes About Possible Support if Found to be HIV Positive

\begin{tabular}{|c|c|c|c|}
\hline & $\begin{array}{c}\text { Uyghur (n=234) } \\
\text { Percent } \\
(\mathbf{9 5} \% \mathbf{C I})\end{array}$ & $\begin{array}{c}\text { Han (n=57) } \\
\text { Percent } \\
(\mathbf{9 5} \% \mathbf{C I})\end{array}$ & $\begin{array}{c}\text { Total (n=291) } \\
\text { Percent } \\
(\mathbf{9 5} \% \mathbf{C I})\end{array}$ \\
\hline \hline $\begin{array}{c}\text { Husband/ } \\
\text { partner }\end{array}$ & $\begin{array}{c}45 \\
(39-51)\end{array}$ & $\begin{array}{c}39 \\
(26-52)\end{array}$ & $\begin{array}{c}44 \\
(38-50)\end{array}$ \\
\hline Parents & $\begin{array}{c}70 \\
(64-76)\end{array}$ & $\begin{array}{c}21 \\
(10-32)\end{array}$ & $\begin{array}{c}60 \\
(54-66)\end{array}$ \\
\hline $\begin{array}{c}\text { Sisters/ } \\
\text { brothers }\end{array}$ & $\begin{array}{c}51 \\
(45-57)\end{array}$ & $\begin{array}{c}43 \\
(3-19)\end{array}$ \\
\hline $\begin{array}{c}\text { Other } \\
\text { relatives }\end{array}$ & $\begin{array}{c}32 \\
(26-38)\end{array}$ & 4 & $\begin{array}{c}27 \\
(22-32)\end{array}$ \\
\hline $\begin{array}{c}\text { From Imams, } \\
\text { priests }\end{array}$ & $\begin{array}{c}30 \\
(24-36)\end{array}$ & $\begin{array}{c}32 \\
(60-60)\end{array}$ & $\begin{array}{c}52 \\
(20-30)\end{array}$ \\
\hline $\begin{array}{c}\text { From hospital, } \\
\text { doctors, nurses }\end{array}$ & $(54-61)$ \\
\hline
\end{tabular}

\section{Attitudes on Coming Pregnancies and Breastfeeding}

Only one Han Chinese women said that she would want to have more children if she were HIV positive as compared with $7(3 \%)$ of the Uyghur women. Among the other women the main reason mentioned by $64 \%$ of Uyghur and $80 \%$ of Han Chinese women was the risk of infecting the baby. Thirty-three percent of the Uyghur and 18\% Han Chinese women had no ideas about this question, $12 \%$ and $32 \%$ of them did not answer.

Seventy-four per cent of the Uyghur and $65 \%$ of the Han Chinese women wrote they would not breastfeed their baby if they were found to be HIV positive. Eight per cent of the Uyghur and $4 \%$ of the Han Chinese women thought they would breastfeed. Eighteen percent and 31\% respectively were undecided.

When asked how many years they thought they would live if they were found to be HIV positive, the majority, 94\% of the Uyghur and $57 \%$ of the Han Chinese women wrote that they didn't know. 


\section{DISCUSSION}

Knowledge and awareness about HIV/AIDS is the most important weapon in the fight against further spread of the virus. Information about HIV to pregnant women associated with a program for mother to child prophylaxis will reduce the women's and their babies' risks of becoming infected, and is therefore lifesaving.

Most of the pregnant women in northwest China had first heard about HIV/AIDS through the media. Many women referred to the AIDS awareness campaigns held on the radio and TV. The second largest source of information was a friend or a relative. In the rural areas this is an important way of disseminating information since access to media is likely to be lower and illiteracy is more widespread [28]. It is noteworthy that women with little education more often answered 'don't know' to the questions than the more educated women. One reason could be that they actually did not know. Another reason could be that they were not used to answering questions like these. Women with less education not only had more difficulties understanding questions but also seemed more afraid of giving the 'wrong' answer.

One of the things that need to be emphasized in continuing health education about HIV is that an HIV positive person does not usually show any signs of disease until they develop AIDS, often many years after becoming HIV positive. A majority of the pregnant women didn't know the signs and symptoms of AIDS.

Only $69 \%$ of the Uygur women and $58 \%$ of the Han Chinese women wanted an HIV test, which is lower than in a similar study among pregnant women in rural India in 2002, where $86 \%$ reported that they wanted an HIV test [29]. Our study results indicate that approximately one third of the pregnant women thought that HIV could be transmitted by social contact. This implies a high risk of excluding HIV positive person from social life. Most importantly, the risks of needle sharing and breastfeeding were poorly understood. It is possible that information about this is less likely to be delivered by the media, where most pregnant women obtained their HIV information. Finding socially acceptable ways to educate pregnant women about these risks is essential to HIV prevention efforts.

The uncertainty about mother-to-child transmission as a route of HIV transmission has also been identified in other studies [30-32]. In contrast to the studies mentioned above, two other similar studies conducted in India [33] and Papua New Guinea [26] report higher percentages, $80 \%$ and $69 \%$, of women knowing about breastfeeding as a route of transmission of HIV from mother-to-child. When it comes to the knowledge about pregnancy and delivery as routes of transmission, around the same percentages of pregnant women in India and Papua New Guinea, as in a Hong Kong study [34] knew about these routes of transmission. Therefore our conclusion is, as in the Hong Kong study, the study from India [33] and the study from Ghana [32] that pregnant women have relatively little knowledge about specific mother-tochild HIV transmission and do not know about means of reducing mother-to-child HIV infection.

\section{CONCLUSIONS}

The pregnant women' awareness and knowledge about HIV/AIDS seems to be superficial. There are still people who have no knowledge of HIV and people with misconceptions about how it is spread. Further campaigns in the media and additional efforts to continue to raise the level of awareness among the people of Aksu are essential.

Testing and counselling for both men and women must be available free of charge. Mothers who test HIV positive need personal counselling and support with information about the option of abortion or antiretroviral therapy and, when medically indicated caesarean section, together with no breastfeeding or exclusive breastfeeding to reduce the likelihood of mother-to-child transmission.

\section{ACKNOWLEDGEMENTS}

We would like to thank Dr. Wang Donghui, Mother and Children Health Care Section of Aksu for introducing us to the staff at the clinic in Aksu. The study has been supported by planning grants from the Research Council of Sweden and the Swedish International Development Cooperation Agency. We thank Secretary Lisbeth Jinnestål Fernow for help with the manuscript.

\section{AUTHORS CONTRIBUTION}

The both authors have together participated in the design of the study. RM has made the interviews, distributed the questionnaires and registered the data. RM has made the analysis of the data together with RA. RA and RM have participated in interpretation of data and preparation of the manuscript. Both authors have read and approved the final manuscript.

\section{REFERENCES}

[1] Nduati R, John G, Mbori-Ngacha D, et al. Effect of breastfeeding and formula feeding on transmission of HIV-1: a randomized clinical trial. J Am Med Assoc 2000; 283: 1167-74.

[2] Miotti PG, Taha TE, Kumwenda NI, et al. HIV transmission through breast feeding: a study in Malawi. J Am Med Assoc 1999; 282: 744-9.

[3] Connor EM, Sperling RS, Gelber R, et al. For the Pediatric AIDS Clinical Trials Group Protocol 076 Study Group. Reduction of maternal-infant transmission of human immunodeficiency virus type 1 with zidovudine treatment. N Engl J Med 1994; 331:1173-80.

[4] Wade NA, Birkhead GS, Warren BL, et al. Abbreviated regimens of zidovudine prophylaxis and perinatal transmission of the human immunodeficiency virus. N Engl J Med 1998; 339:1409-14.

[5] Guay LA, Musoke P, Fleming T, et al. Intrapartum and neonatal single-dose nevirapine compared with zidovudine for the prevention of mother-to-child transmission of HIV-1 in Kampala, Uganda: HIVNET 012 randomised trial. Lancet 1999; 354: 795802 .

[6] The Petra Study Team. Efficacy of three short-course regimens of zidovudine and lamivudine in preventing early and late transmission of HIV-1 from mother to child in Tanzania, South Africa, and Uganda (Petra Study): a randomized, double-blind, placebocontrolled trial. Lancet 2002; 359: 1178-86.

[7] Chaisilwattana P, Chokephaibulkit K, Chalermchockcharoenkit A, et al. Short-course therapy with zidovudine plus lamivudine for the prevention of mother-to-child transmission of human immunodeficiency virus type 1 in Thailand. Clin Infect Dis 2003; 35: 1405-13.

[8] Fowler MG, Newell ML. Breastfeeding and HIV-1 transmission resource limit settings. J Acquir Immune Defic Syndr 2002; 30: 216-29.

[9] WHO collaborative study team on the role of breastfeeding on the prevention of infant mortality: Effect of breastfeeding on infant and 
child mortality due to infectious disease in less developed countries: a pooled analysis. Lancet $2002 ; 355$ : 451-5.

[10] Bland RM, Rollins NC, Cousoudis A, Coovadia HM. For the Child Health Group. Breastfeeding practices in an area of high prevalence in rural South Africa. Acta Paediatr 2002; 91: 704-11.

[11] Hocke C, Morlat P, Chene G, Dequae L, Dabis F. Groupe d'Epidemiologie Clinique du SIDS en Aquitaine. Prospective cohort study of the effect of pregnancy on the progression of human immunodeficiency virus infection. Obstet Gynecol 1995; 86: 88691.

[12] The EACS Euro Guidelines Group. European guidelines for the clinical management and treatment of HIV- infected adults in Europe. AIDS 2003; 17(supp1 2): S3-S26.

[13] Frenkel L, Wagner L, Demeter L, et al. Effects of zidovudine use during pregnancy on resistance and vertical transmission of HIV-1. Clin Infect Dis 1995; 20:1321-6.

[14] Eastman PS, Shapiro DE, Coombs RW, et al. Maternal viral genotypic zidovudine resistance and infrequent failure of zidovudine therapy to prevent perinatal transmission of human immunodeficiency virus type 1 in pediatric AIDS Clinical Trial Group Protocol 076. J Infect Dis 1998; 177: 557-64.

[15] Garcia PM, Kalish LA, Pitt J, et al. Maternal levels of plasma human immunodeficiency virus type 1 RNA and the risk of perinatal transmission. Women and Infants Transmission Study Group. N Engl J Med 1999; 341: 394-402.

[16] Mofenson LM, Lambert JS, Stiehm ER, et al. Risk factors for perinatal transmission of human immunodeficiency virus type 1 in women treated with zidovudine. Pediatric AIDS Clinical Trial Group Study 185 Team. N Engl J Med 1999; 341:385-93.

[17] Sperling RS, Shapiro DE, Coombs RW, et al. Maternal viral load, zidovudine treatment, and the risk of transmission of human immunodeficiency virus type 1 from mother to infant. Pediatric AIDS Clinical Trials Group Protocol 076 Study Group. N Engl J Med 1996; 335: 1621-9.

[18] Natal K. Provincial Department of Health. Protocol for the phased implementation of a comprehensive package of care for the prevention of mother to child transmission of HIV in KwaZulu Natal. $4^{\text {th }}$ ed, 2003.

[19] Lallemant M, Jourdain G, Le Coeur S, et al. Single-dose perinatal nevirapine plus standard zidovudine to prevent mother-to-child transmission of HIV-1 in Thailand. N Engl J Med 2004; 351: 217 28.

[20] Dabis F, Bequet L, Ekouevi DK, et al. Field efficacy of zidovudine, lamivudine and single-dose nevirapine to prevent peripartum HIV transmission. AIDS 2005; 19: 309-18.
[21] Thorne C, Newell ML. Treatment options for the prevention of mother-to-child transmission of HIV. Curr Opin Investig Drugs 2005; 6: 804-11.

[22] Settle E. AIDS in China: an annotated chronology: 1985-2003. Montreal: China AIDS Survey 2003.

[23] State Council AIDS Working Committee Office, UN Theme Group on HIV/AIDS in China. A joint assessment of HIV/AIDS prevention, treatment and care in China. Beijing: China Ministry of Health 2004

[24] Ministry of Health of China, UNAIDS, WHO. 2005 update on the HIV/AIDS epidemic and response in China. Beijing: Ministry of Health 2006.

[25] State Council HIV/AIDS Working Committee Office and UN Theme Group on HIV/AIDS in China. "A Joint Assessment of HIV/AIDS Prevention, Treatment and Care in China” 2004

[26] Andersson M, Sandström C, Mola G, Amoa AB, Andersson R Yauieb A. Awareness of and attitudes towards HIV among pregnant women at the Antenatal Clinic, Port Moresby General Hospital. PNG Med J 2003; 46: 152-63.

[27] Colton T. Statistics in medicine. Little Brown and Company, Boston 1974 .

[28] Post-Courier. Illiteracy bigger killer than AIDS, Post- Courier Online, 16 Jan 2003.

[29] Tillich M, Nilsson A. Awareness, attitude and prevention of HIV among pregnant women in Maharashtra State, India. Diploma thesis, Gothenburg University 2003. Available at: http://www.vgregion.se/vgrtemplates/Page 42879.aspx

[30] Hesketh T, Duo L, Li H, Tomkins AM. Attitudes to HIV and HIV testing in high prevalence areas of China: informing the introduction of voluntary counselling and testing programmes. Sex Transm Infect 2005; 81: 108-12.

[31] Okonkwo KC, Reich K, Alabi AI, Umeike N, Nachman SA. An evaluation of awareness: attitudes and beliefs of pregnant Nigerian women toward voluntary counselling and testing for HIV. AIDS Patient Care and STDs 2007; 21: 252-60.

[32] Addo VN. Pregnant women's knowledge of and attitudes to HIV testing at Komfo Anokye Teaching Hospital, Kumasi. Ghana Med J 2005; 39: 50-4.

[33] Rogers A, Meundi A, Amma A, et al. HIV-related knowledge, attitudes, perceived benefits, and risks of HIV testing among pregnant women in rural southern India. AIDS Patient Care and STDs 2006; 20: 803-11.

[34] Choi Fung Ho, Alice Yuen Loke. HIV/AIDS knowledge and risk behaviour in Hong Kong. Chinese pregnant women. J Adv Nurs 2003; 43: 238-45.

Received: March 11, 2008

Revised: June 20, 2008

Accepted: August 19, 2008

(C) Maimaiti and Andersson; Licensee Bentham Open.

This is an open access article licensed under the terms of the Creative Commons Attribution Non-Commercial License (http://creativecommons.org/licenses/by$\mathrm{nc} / 3.0 /$ ) which permits unrestricted, non-commercial use, distribution and reproduction in any medium, provided the work is properly cited. 